\title{
REVERSE LOGISTICS IN THE EDITORIAL SECTOR: \\ AN EXPLORATORY STUDY
}

\author{
Juan Pablo Soto \\ Cristina Gimenez \\ Helena R. Lourenço ${ }^{1}$ \\ Research Group in Business Logistics (GREL) \\ Department of Economics and Business \\ Universitat Pompeu Fabra
}

April 2005

\begin{abstract}
Nowadays, the Reverse Logistics field is becoming very important. On one hand, laws are imposing companies to be responsible for the contamination made by their products. On the other hand, companies have discovered the profits derived from a good Reverse Logistics process. This paper is the result of the work done by a group of companies from the Spanish Editorial sector to understand and improve their Reverse Logistics process. The paper describes the characteristics of the Reverse Logistics process in this sector and the improvements identified by the "work group".
\end{abstract}

Key words: Reverse Logistics, editorial industry, Supply Chain Management, Returns, case study. JELC: M11,L60.

\section{INTRODUCTION}

Reverse Logistics $(R L)$ is the "reverse" way of doing Logistics. RL includes all the activities referred to remanufacturing, products returns, disassembly processes, etc. RL is defined by Rogers and Tibben-Lembke (1998) as "The process of planning, implementing, and controlling the efficient, cost effective flow of raw materials, in-process inventory, finished goods and related information from the point of consumption to the point of origin for the purpose of recapturing value or proper disposal".

Today, RL is a very important issue for companies. On one hand, laws are becoming more demanding every day. During the next years, in the EU, companies will be responsible for the contamination derived from their products. The objective of this legislation is to make companies more conscious about the environment and their responsibility with its preservation. And, on the other hand, companies have discovered the potential profit derived from an efficient

${ }^{1}$ Department of Economics and Business, Universitat Pompeu Fabra, R. Trias Fargas 25-2708005 Barcelona, Spain; juan.soto@upf.edu, cristina.gimenez@upf.edu, helena.ramalhinho@upf.edu. 
$\mathrm{RL}$ process. For example, Xerox started a program which consisted on using the returned copy machines to manufacture the new ones. In 1997, Xerox Europe took back about 160,000 Xerox machines from customer sites in Europe (a 6\% increase over 1996), out of which it reprocessed over 3.8 million parts. In the last few years, Xerox Europe's remanufacturing initiative has been emulated by its major competitors, which demonstrates the impact it has had on the marketplace (see Maslennikova and Foley 2000).

Rogers and Tibben-Lembke (1998) estimated that RL costs account for \$35 billions of dollar per year in the EEUU (4\% of the total logistics costs), with an average return rate of $6 \%$ over sales. They also found that distributors implementing RL programs achieved savings between 1 to $3 \%$ of their sales.

Companies are looking for different strategies and technologies to improve their $\mathrm{RL}$ process. Lourenço and Soto (2003) described three main areas of improvement within the RL process. Firstly, companies can reduce the level of returns through the analysis of their causes. Secondly, they can work on the improvement of the return's process and, thirdly, they can create value from the returns.

The overall amount of $\mathrm{RL}$ activities in the companies is large and still growing. However, the magnitude and impact of RL varies with the industry, channel position and channel choice. One of the sectors where returns are becoming a big handicap is the editorial industry. The Spanish editorial sector, one of the leaders in the world with nearly 2500 millions of Euros of sales annually, has an average return rate of $41,17 \% \%^{2}$ of the sales. For this reason, $\mathrm{RL}$ is a topic of importance among professionals in the editorial sector. However, it has not been considered as an outstanding topic in the RL literature. None of the existing studies considers this industry. The objectives of this paper are: to describe and analyse the RL process within this industry and to propose some ways to improve it.

We believe that this paper will be both informative and insightful to managers and researches in the SCM field. Managers are provided with some guidelines

\footnotetext{
${ }^{2}$ Federación Nacional de Gremios de Editores, Spain, 2001.
} 
to improve the RL process. And, researchers are given some lines of further research.

The paper is structured as follows: section two briefly examines the literature on $\mathrm{RL}$; section three describes the characteristics of the Spanish editorial sector. Section four shows the research methodology; section five presents the results, section six provides some conclusions and lines of future research and, finally, in the appendixes we present some questionnaires and documents used during the research process.

\section{LITERATURE REVIEW}

For the scope of this paper we will consider RL as it was defined by Rogers and Tibben-Lembke (1998): "The process of planning, implementing, and controlling the efficient, cost effective flow of raw materials, in-process inventory, finished goods and related information from the point of consumption to the point of origin for the purpose of recapturing value or proper disposal".

Some authors have performed exploratory studies to determine the "state of the art" of RL in other countries and other industries (see Kroon and Vrijens (1994), Barros et al. (1998), Fraser (1998), RLEC (1999), Kokkinaki, et al. (1999), Krikke et al. (1999) and, Goodman (2000)), but there is not any evidence of this kind of work in Spain.

Kroon and Vrijens (1994) considered a practical application of RL in the reuse of secondary packaging material. They present a number of methods that may be used to create a return logistic system for returnable containers. They presented a quantitative model and a case study. Barros et al. (1998) conducted a case study in the construction industry. They analysed a two-level network responsible for recycling sand. The paper described the RL process but it also proposed a mathematical model to decide the most efficient location of the recycling containers. Fraser (1998) explored the role of purchasing and other functional areas in the RL systems of 12 North American manufacturing plants. The Reverse Logistics Executive Council (RLEC) sponsored several studies to assess the state of the art of the RL process in the apparel, electronics and small appliances industries (see RLEC, 1999). Kokkinaki et al. 
(1999) conducted an exploratory study to analyse the RL services provided by companies selling in the e-commerce channel. They classified the internet sites object of study and described their RL processes. Krikke et al. (1999) described the case of Roteb, the municipal waste company of Rotterdam, which implemented some recovery strategies for PC-monitors. And, finally, Goodman (2000) described how sustainable operations in Scandic hotels were performed and the savings achieved.

Our study shares with Kroon and Vrijens (1994), Fraser (1998), Barros et al. (1998), Krikke et al. (1999), Kokkinaki et al. (1999) and Goodman (2000) the use of the case study methodology. Researchers are claiming the use of more case study based papers (see, for example, Voss et al. 2002). But our study differs from the existing ones in the industry object of study. Our study focus on the editorial industry, which is characterised by a high return rate. Editorial companies have, in average, nearly 1 book returned for each 2 books sent to the market. Our objectives are to describe and analyse the RL process and to identify how this process can be improved.

In the next section we describe the main characteristics of the Spanish editorial sector.

\section{THE SPANISH EDITORIAL SECTOR}

The Spanish editorial industry is the fifth on the world ranking according to the sales figure (2.450 millions of Euros). It represents $0,6 \%$ of the Spanish GDP. The business network is composed by 2000 editorial producers, with approximately 13.000 direct employees. $80,5 \%$ of the production corresponds to private editorial companies, $12,5 \%$ to public companies and the remaining part $(7 \%)$ is distributed between ONG's and individual editors.

One important characteristic of this sector, is the high rate of product introduction. Every day 175 new titles are introduced in the market. Also, it is important to remark that the volume of the average production by title is decreasing every year. This implies that editors have to make a great effort to sell their products. 
Book sales are mainly done through bookstores; however, sales through hypermarkets have been increasing during the last years. This is leading to a higher competitive environment, as hypermarkets are pressing editorial companies for reducing prices.

Regarding the distribution system it has to be pointed out that there is not a unique distribution system. Some editors have their own distribution network. Others combine their own network with the network provided by a Third Party Logistics (TPL) company. And, other companies use the postal service to send some urgent deliveries. The trend is to increase the use of TPL to distribute the goods. Some of these TPL companies provide this service exclusively to a specific editorial company, while others work simultaneously for different editors.

The cost per unit in $R L$ is very high due to the high manipulation required and the lack of economies of scale. Companies can not benefit from economies of scale in $\mathrm{RL}$ because the batches are usually lower than in the direct logistics. In some cases, they become unitary batches. For example, editors have to assess quality book by book. This, added to the high returns rate existing in the editorial sector, makes the $\mathrm{RL}$ costs be considerably higher than the direct logistics costs.

The returns volume is different for each type of publication (periodic and nonperiodic publications). Figure 1 shows the different types of publications and their main characteristics.

In periodic publications, the return volume is usually higher than in the nonperiodic publications. Companies usually receive all the non-sold products and they have to destroy them. These are usually goods with short life cycle, and they cannot be on sale once the period of commercialisation expires. The RL process of this group of publications is only concerned with the collection of the final products once the commercialisation period has expired. Due to the short life cycle and the need to have the right number of publications to avoid lost sales and minimize returns, the objective of the editorial companies for this group of publications is to obtain "good" forecasts. In the market, there are many software companies which offer good forecasting solutions for the periodic publications group. 
Within the non-periodic publications we have two different subgroups: text books and general editions. Text books include all the books sold to schools and universities. These books are sold through the traditional channels (such as bookstores, hypermarkets, etc) and directly to the schools and universities. The seasonality of this type of books is easily identified and is concentrated in few weeks. The returns period is also small and clearly defined. Returns in text books are lower than in the general editions. Forecasting for text books is easier than in the general editions case, given that the number of students passing from one course to another can be more easily determined.

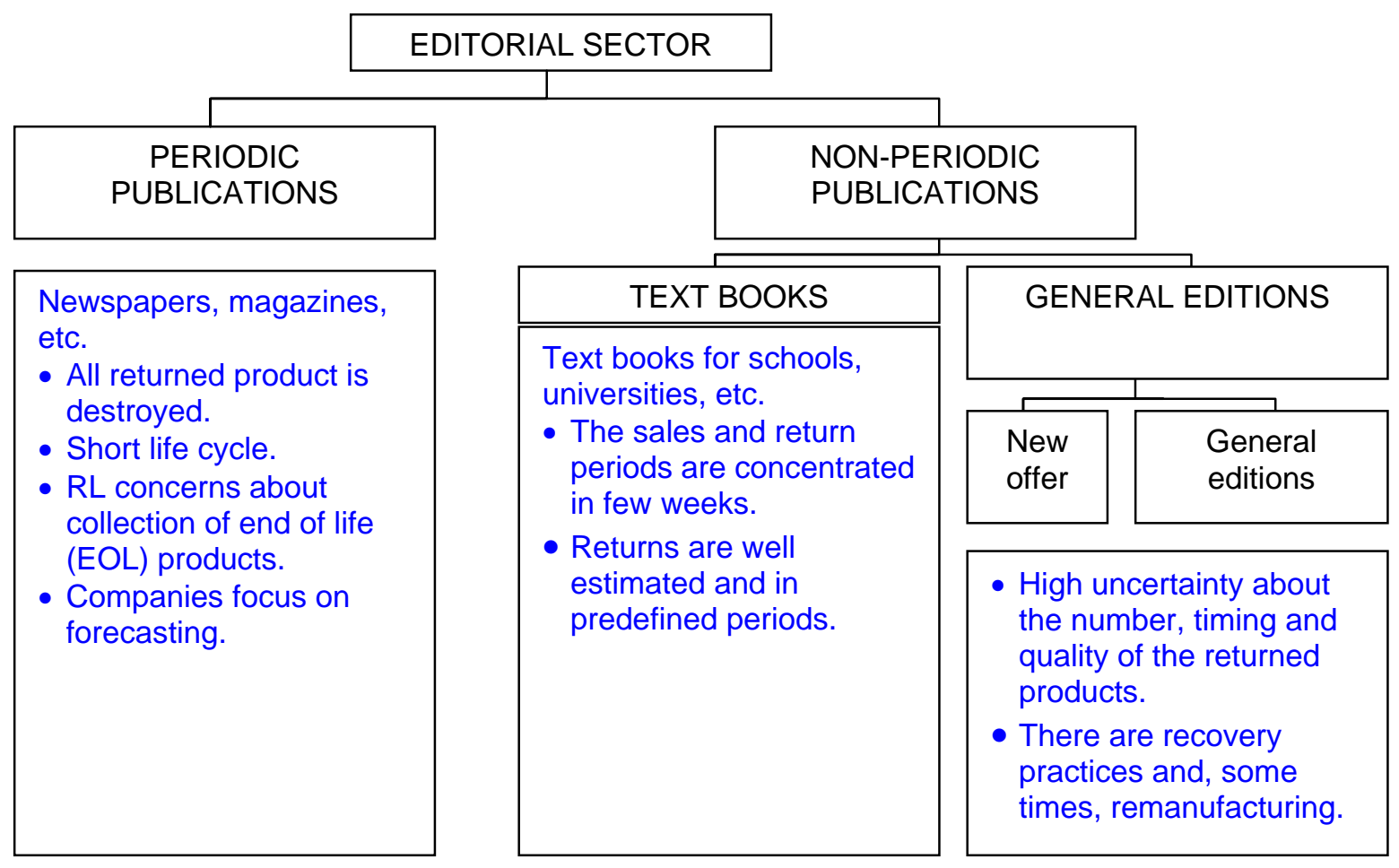

Figure 1.Editorial products and their characteristics

General editions include the rest of books, which are sold during all the year. In this group there is also some seasonality during special events or dates but, in general, there is a constant flow of goods forward and backward. There is not any knowledge about how much, when, where and how the goods are sold and returned. This makes this group of products the most problematic one. Our work will be mainly focused in the analysis of this group of publications.

For further details about the Spanish editorial sector see FANDE (2003). 


\section{RESEARCH METHODOLOGY}

The research methodology used was based on Malhotra (2004). He defines two different types of research design: conclusive research design and exploratory research design (see figure 2). The objective of the conclusive research design is to test specific hypothesis and examine relationships. In this kind of studies, the information needed is clearly defined, the research process is formal and structured, samples are large and representative and the data analysis is usually quantitative. On the other hand, the objective of the exploratory research design is to discover ideas or to provide insights and understanding about something. This kind of studies is characterized by a flexible and versatile research process. The samples are usually small and the analysis is basically qualitative. The methods recommended for this kind of research are: expert surveys, pilot surveys, secondary data and qualitative research, among others.

In order to obtain a deep knowledge of the actual state of the RL process in the editorial sector in Spain, we have conducted an exploratory multiple case study using the methodologies recommended by Malhotra (workgroups, visits and interviews).

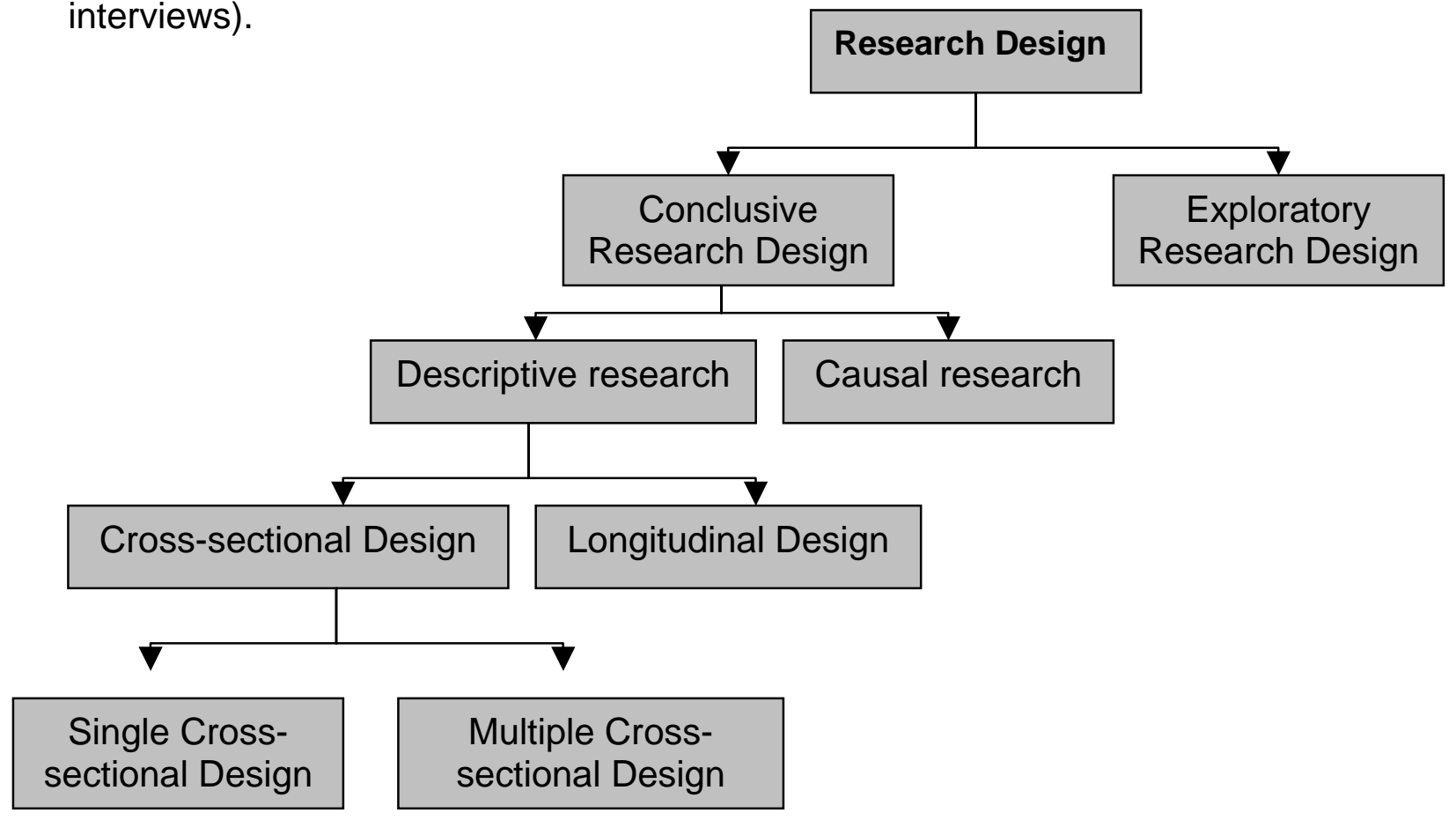

Figure 2. A classification of Research Designs. Malhotra (2004) 
The case study methodology followed was adopted from Yin (1994). Figure 3 summarizes the main steps.

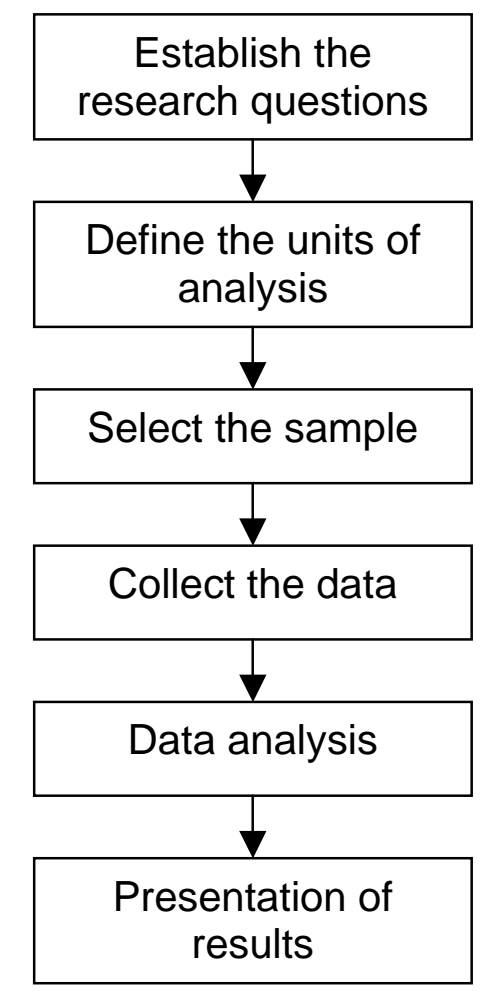

Figure 3. Case study methodology. Adapted from Yin (1994)

First, the research questions were established:

1. How is the RL process in the editorial sector?

2. How are Spanish editorial firms in each one of the three areas of work within the RL process (Reduction of returns, process improvement and, creation of value from returns)?

3. How can the RL process be improved?

The next step consisted on defining the units of analysis and selecting the sample. The units of analysis chosen were Spanish editorial companies. Initially, the Logistics Managers of sixteen editorial firms were contacted and invited to participate in a work group on RL conducted by the Centro Español de Logística (CEL) and the Research Group in Business Logistics (GREL) of Universitat Pompeu Fabra. Eleven companies accepted the invitation. Table 1 summarizes the characteristics of these companies. 
As stated in section 3, due to the complexity of the returns management of the general editions category our work was focused on this category of products.

To gather the data we decided to use different techniques: surveys, meetings and company visits. Table 2 presents the three research questions related to our objectives, the aspects needed to be analysed to answer each research question and the technique used to collect the data.

\begin{tabular}{|l|l|l|}
\hline COMPANY & \multicolumn{1}{|c|}{ \% RETURNS } & \multicolumn{1}{c|}{ SALES IN EUROS } \\
\hline Company 1 & $21 \%-25 \%$ & 55.000 .000 \\
\hline Company $\mathbf{2}$ & $17 \%-12 \%$ & 2.003 .980 \\
\hline Company 3 & $0 \%-35 \%$ & 80.500 .000 \\
\hline Company 4 & $15 \%-30 \%$ & 162.000 .000 \\
\hline Company 5 & $17 \%-12 \%$ & 21.317 .133 \\
\hline Company 6 & $37 \%-35 \%$ & 22.847 .916 \\
\hline Company 7 & $0 \%-35 \%$ & 901.518 .000 \\
\hline Company 8 & $37 \%-35 \%$ & 484.558 .000 \\
\hline Company 9 & - & 1.905 .000 .000 \\
\hline Company 10 & $25 \%$ & - \\
\hline Company 11 & - & 66.000 .000 \\
\hline
\end{tabular}

Table 1. Companies participating in the study

To collect the data, the work group was created in December 2001. In the first meeting, the research project with its three main research questions was presented. We met every 2 or 3 months, depending on the work load of the participants. After each session a summary was written for our case study database. The process followed was: Firstly, we defined the RL process. Then, we conducted the exploratory survey. With the results of the survey, the group continued working on the discussion of how to improve the Returns Management. The project ended in September 2003. The questionnaire used to conduct the survey can be observed in appendix I.

In the next section we present the case study results. 


\begin{tabular}{|c|c|c|}
\hline & QUESTION & METHODOLOGY \\
\hline \multicolumn{3}{|c|}{ RQ1. How is the RL process in the editorial sector? } \\
\hline 1.1 & $\begin{array}{l}\text { Which is the RL process the } \\
\text { editorial companies are } \\
\text { following? }\end{array}$ & $\begin{array}{l}\text { - Teamwork } \\
\text { - Companies' presentations } \\
\text { - Visits. }\end{array}$ \\
\hline \multicolumn{3}{|c|}{$\begin{array}{l}\text { RQ2. How are the Spanish editorial firms in each one of the three areas of } \\
\text { work within the RL process (Reduction of returns, Improvement of the } \\
\text { return's process, creation of value from the returns)? }\end{array}$} \\
\hline 2.1 & $\begin{array}{l}\text { How are they in terms of } \\
\text { knowledge about their returns } \\
\text { and their causes? }\end{array}$ & $\begin{array}{l}\text { - Survey: } \\
\text { Q1: In which percentages the following causes of } \\
\text { return are present in your company? } \\
\text { Q2: What are the returns' rates of your company in } \\
\text { each one of the following items? } \\
\text { - Companies' presentations } \\
\text { - Visits. }\end{array}$ \\
\hline 2.2 & $\begin{array}{l}\text { Which is the performance of the } \\
\text { returns process? }\end{array}$ & $\begin{array}{l}\text { - Survey: } \\
\text { Q6: What are the principal causes of discussion } \\
\text { with your clients in terms of returns' } \\
\text { management? } \\
\text { Q8: Do you know what is the average cost of } \\
\text { returning a book to your company? } \\
\text { Q9: In case of yes, How do you calculate it? i.e. } \\
\text { what are the elements included in this } \\
\text { calculation?. } \\
\text { Q10: What percentage of the return costs } \\
\text { corresponds to...? } \\
\text { - Companies' presentations } \\
\text { Visits. }\end{array}$ \\
\hline 2.3 & $\begin{array}{l}\text { Are they creating value from the } \\
\text { returns? }\end{array}$ & $\begin{array}{l}\text { - Survey: } \\
\text { Q4: What is the percentage in which you perform } \\
\text { each one of the following practices with the } \\
\text { returned products in your company? } \\
\text { - Companies' presentations } \\
\text { - Visits. }\end{array}$ \\
\hline \multicolumn{3}{|c|}{ RQ3. How can the Returns Management be improved? } \\
\hline 3.1 & Can the returns be reduced? & $\begin{array}{l}\text { - Discussion } \\
\text { - Teamwork }\end{array}$ \\
\hline 3.2 & $\begin{array}{l}\text { How can the RL process be } \\
\text { improved? }\end{array}$ & $\begin{array}{l}\text { - Survey: } \\
\text { Q3: What kind of useful information can be } \\
\text { provided by your clients or distributors in order to } \\
\text { improve the RL processes? } \\
\text { Q5: If you should work together with clients and } \\
\text { distributors in RL, what do you believe that are } \\
\text { the priorities of the work? } \\
\text { Q7: What kind of information you think is useful to } \\
\text { know in returns management? } \\
\text { - Discussion } \\
\text { - Teamwork }\end{array}$ \\
\hline 3.3 & $\begin{array}{l}\text { How can more value be created } \\
\text { from returns? }\end{array}$ & $\begin{array}{l}\text { - Discussion } \\
\text { - Teamwork }\end{array}$ \\
\hline
\end{tabular}

Table 2. Research questions and methodology used 


\section{RESULTS}

The results are presented in terms of the Research Questions.

\subsection{RQ1: How is the RL process in the editorial sector?}

The first question is related with the actual RL process in the editorial sector. To better understand how they are performing this process, we used two different methodologies. Firstly, we asked the companies to make a presentation explaining how they were performing this process, and then, we visited the distribution plants of some of the companies in order to extend the knowledge acquired with the presentations.

From the presentations, the visits and some additional documents the companies provided us, we evaluated the differences and common issues between the companies regarding the RL process. In this paper, we consider that the $\mathrm{RL}$ process starts when the company receives the information about the return of a product, and finalizes when the product is disposed or eliminated.

For simplicity we evaluate the transportation process independently from the rest of the RL process. The following two sections describe these processes.

\subsubsection{The transportation process}

The process starts when a client decides to return a good. Practices vary not only between companies, but also within the companies. There are two different ways of doing the transportation process:

a. The product is retrieved by the editor from the client's stores: In this case, returns are made when orders are delivered to the client. The normal practice is that the editor gives an authorization that determines the products that can be retrieved. However, some editors follow the policy of receiving everything from the clients without any explicit authorization. The editor is responsible for all the costs. The common practice is to transport the products to an intermediate warehouse, from where, once the books are consolidated, they are returned to the central warehouse.

b. The product is send by the client to the Editor: In this case, the client is usually responsible for the transportation costs. 
c. The product is send by the client to the editor with authorization: In this case the editor pays the transportation costs, but he specifies the transportation company. The products can be sent to a central warehouse or to an intermediate warehouse.

The most common practice is that the editor picks up the books from the client with its transportation resources (own or outsourced) (option a). If the client decides to send back the books without the editor's authorization, then it has to pay for the transportation fees and it assumes the risk of not having the books accepted by the editor (option b). As it can be appreciated in table 3, these two options are the common practice in all the companies analysed.

\begin{tabular}{|l|c|}
\hline COMPANY & $\begin{array}{c}\text { TRANSPORTATION } \\
\text { PROCESS USED }\end{array}$ \\
\hline Company 1 & $\mathrm{a}, \mathrm{b}, \mathrm{c}$ \\
\hline Company 2 & $\mathrm{a}, \mathrm{b}$ \\
\hline Company 3 & $\mathrm{a}, \mathrm{b}$ \\
\hline Company 4 & $\mathrm{a}, \mathrm{b}, \mathrm{c}$ \\
\hline Company 5 & $\mathrm{a}, \mathrm{b}, \mathrm{c}$ \\
\hline Company 6 & $\mathrm{a}, \mathrm{b}, \mathrm{c}$ \\
\hline Company 7 & $\mathrm{a}, \mathrm{b}$ \\
\hline Company 8 & $\mathrm{a}, \mathrm{b}$ \\
\hline Company 9 & $\mathrm{a}, \mathrm{b}, \mathrm{c}$ \\
\hline Company 10 & $\mathrm{a}, \mathrm{b}, \mathrm{c}$ \\
\hline Company $\mathbf{1 1}$ & $\mathrm{a}, \mathrm{b}$ \\
\hline
\end{tabular}

Table 3. Transportation process for the companies

When the client has some books to return and the editor can not pickup the books, the editor authorizes the client to send the books through an agreed TPL (option c). As it can be appreciated in table 3, only six of the eleven companies have this practice.

\subsubsection{The rest of the $R L$ processes}

These processes are usually known as the internal processes. They start when the return arrives to the company. The basic activities we identified in the internal return process are: 
1. Product reception

2. Refunding

3. Quality assessment

4. Legal certification for destroying the books

5. Other classifications

6. Recovery

7. Disposition practices

We identified some differences between the order in which the different processes are performed in different companies. However, the basic activities are almost the same for all of them. Now, we will describe and analyse some aspects of each one.

1. Product reception: In this stage of the process, the product is received. This means that the product is physically located in the editor's warehouse. The client is still the owner of the product. The ownership of the product is only transferred to the editor when the refunding has been done. Products are retained in this stage until they pass to the next stage of the process. The duration of this process can vary, depending on the company, between a couple of hours and 30 days.

2. Refunding: This process consists on transferring the ownership of the product from the client to the editor, and refunding the money to the client. To refund the money, companies follow different strategies. The most extended practice is to reduce this quantity from the next customer's invoice. Other practice is to make a payment order with the same lead time applied to the client in its orders.

Most of the companies perform this process before the quality assessment process, but some do it after. The position of this activity in the total process has several logistical implications. Doing the process later implies that the owner of the products is still the client, and therefore, in the warehouse, its products have to be together. This means that these products cannot be reorganized with other logistical criteria. As a result, the logistics costs increase (due to manipulation problems) and customer service decreases (due to the fact that the accumulated stock levels in the reception area delay the whole RL process). 
3. Quality assessment: The quality assessment process is very costly in terms of time and personnel because each book must be evaluated individually. The quality assessment is made following some empirical rules previously established. Is in this process when the disposition practice for each individual book is decided. There are basically three quality states: excellent quality, recoverable and non-recoverable. If the quality is excellent, the products are usually reincorporated to the inventory and sold like the new ones. If in the quality assessment of the product, it is considered "recoverable", then it is sent to the recovery process described below. And finally, if the quality statement is non- recoverable, then the product is either sent to the landfill or returned to the client. The general rule is to do not accept the product if the quality state is non-recoverable, but not all companies follow this rule.

In some companies, there is a previous quality assessment classification, where the editor decides if the product should be accepted or rejected. If it is accepted the product continues to a more detailed quality assessment; if it is rejected, then the book is returned to the client.

4. Legal certification for destroying the books: When books are selected to be destroyed a legal certification must be obtained.

5. Other classifications: In some cases additional classifications are performed. For example, if a third party logistics company is performing the RL process for different editors, it has to classify the books by editors. Also, many editors decide to classify the books by title, reference, etc. These additional classifications are made in order to develop economies of scale in manipulation and storage.

6. Recovery: If the quality assessment for the product is "recoverable", then the product needs to pass through a recovery process. The objective of this recovery process is to do some activities on the book in order to have it in a like-new state. This recovery process can vary depending on the problem of the book. The most common problem is that books are returned with the price ticket; in this case the recovery process becomes to take out the ticket. Another problem can be that the cover is not clean. In this case the practices are: to clean the cover or to change it. All these processes are manual and, therefore, with a high cost for the organization. One of the eleven companies decided to 
outsource this recovery process to a third party company in order to reduce costs.

7. Disposition practices: There are different disposition practices within the companies: If the product is "recoverable" or it has perfect quality, then it is reincorporated into the inventory. Most books follow this path. If the product is "not recoverable" the disposition practices are: to sell it through secondary markets, give it for charity, to destroy it or to reject it and return it to the client.

Some books returned pass through a special channel of urgencies. For example, if a book is in stock out and is returned, then this product has priority in all the processes. In this case, the reception, quality assessment and classification of the product and refunding are done quickly in order to reintroduce the book to the inventory as soon as possible.

Table 4 shows the processes followed by each one of the companies analysed. In order to clarify the RL process followed by each one of the companies, we decided to enumerate the activities performed during the process as follows:

1. Product Reception

2. Refunding

\subsection{Invoicing}

2.2. Discount

3. Quality Assessment

3.1. Accept - reject inspection

3.2. Quality level assessment

4. Legal certification for destroying the book

5. Other classifications

5.1. By references, collections or titles

5.2. By editors

5.3. By clients

6. Recovery

6.1. Take out the ticket

6.2. Cleaning

6.3. Change of cover

6.4. Borders cut

7. Disposition Practices 


\subsection{Inventories}

7.2. Secondary markets

\subsection{Charity}

7.4. Returned to the client

\subsection{Elimination}

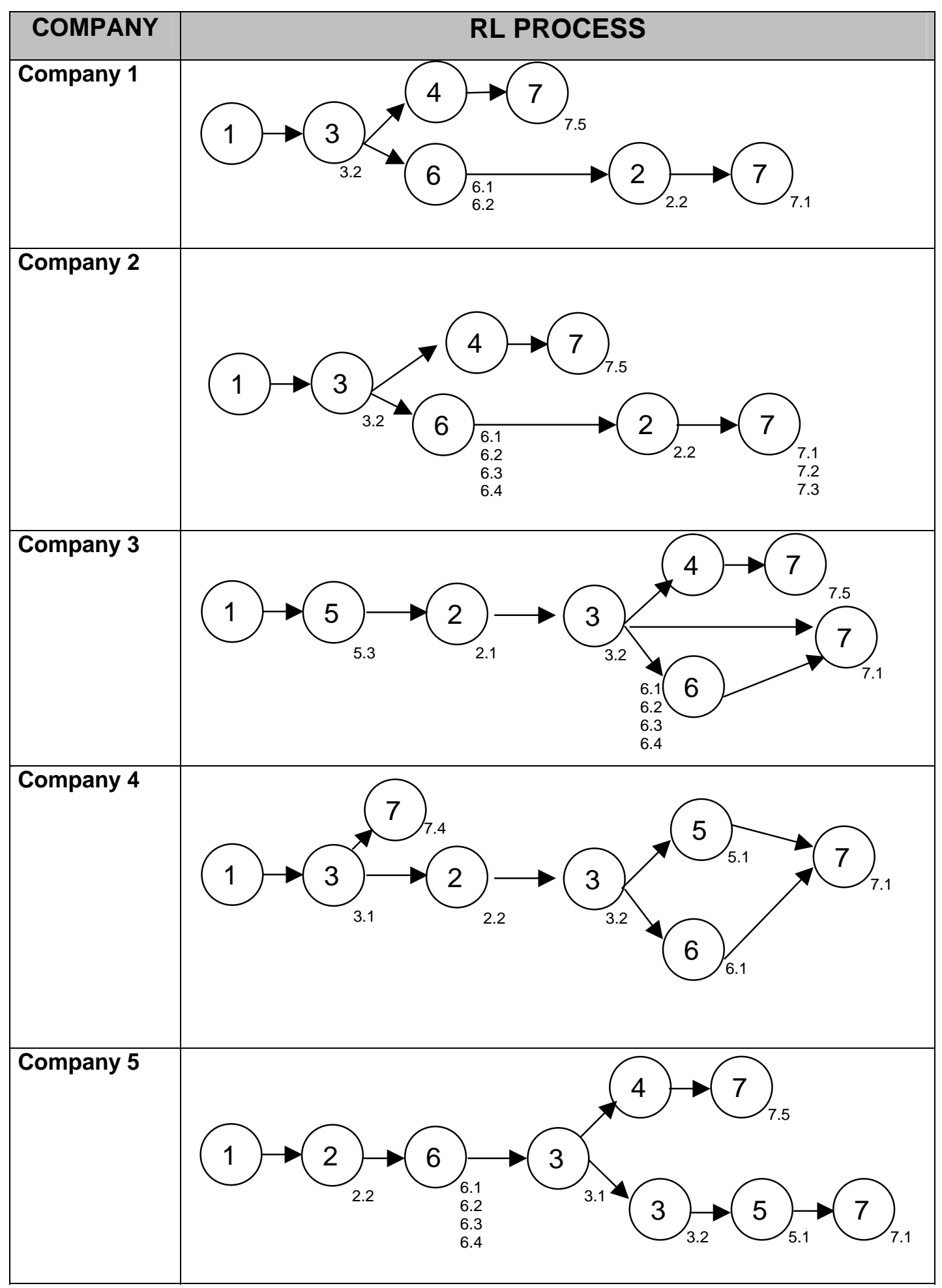




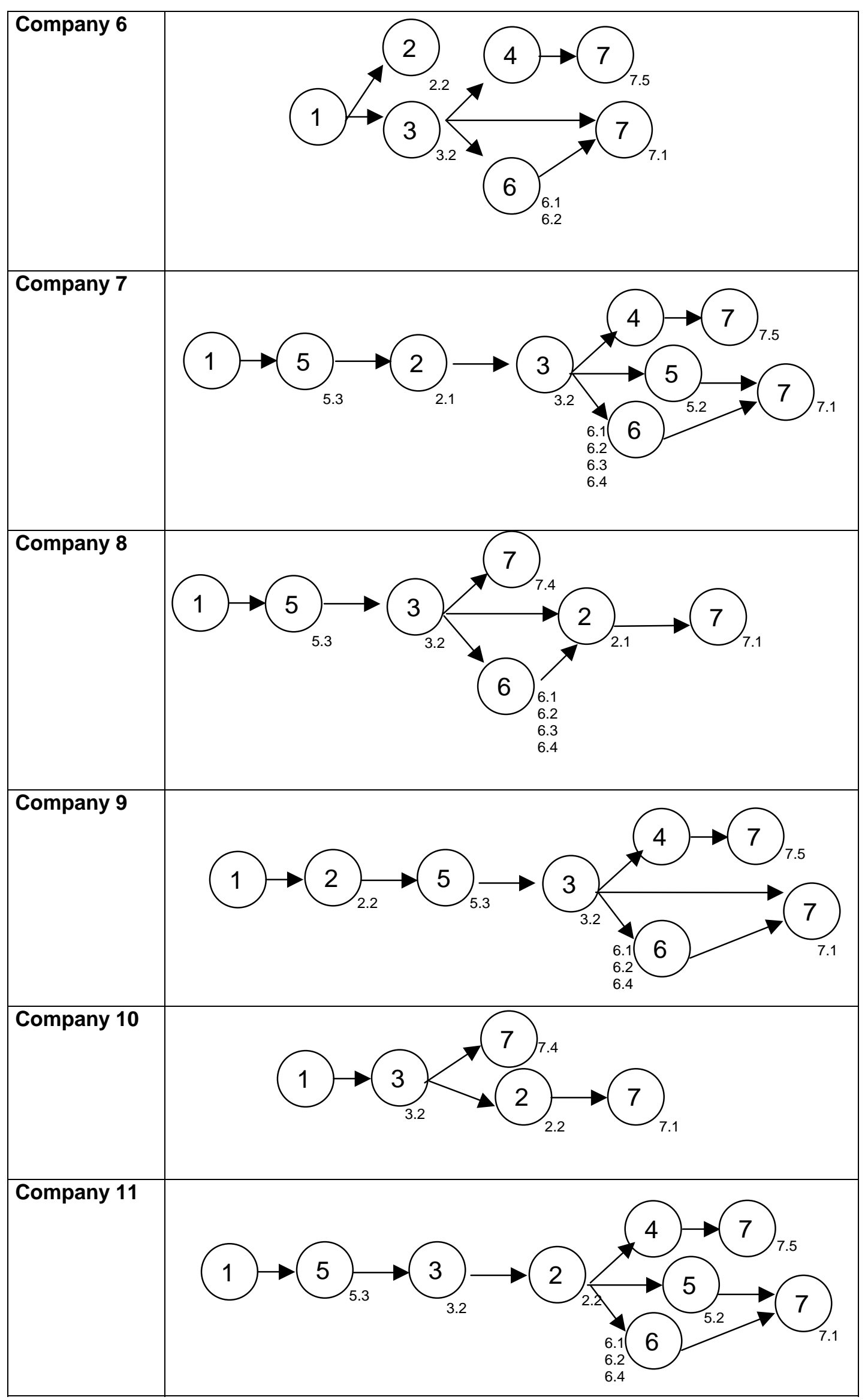

Table 4. Process followed by each one of the companies. 
This table shows that five of the eleven companies do the quality assessment before refunding, while six refund the money of the returns despite of the state in which they arrive. As stated before, the order in which the refunding is done has logistical and financial implications. Other issue to remark is that not all the companies follow the same recovery process. All of them usually clean the book and take out the price ticket (if present), but not all of them cut the borders of the books or change the cover. In fact, only five of them change the cover of the books, and they only do this for those books who have a luxury design. Seven editors cut the borders of the books (if needed). Finally, in terms of the disposal activities, it has to be noticed that all the companies usually reincorporate the products to the inventory. There is only one company that sends the books to charity or secondary markets.

\subsection{RQ2: How are the Spanish editorial firms in each one of the three areas of work within the RL process (Reduction of returns, Improvement of the return's process, creation of value from the returns)?}

Lorenço and Soto (2003) identified three main areas of work: causes of returns, improvement of the $\mathrm{RL}$ processes and value creation from the returns. The objective of this research question is to determine how are the Spanish editorial companies in these three areas of work. In order to answer this research question data was gathered using a survey and companies' presentations and visits. In the following sections we analyse each one of these three areas of work.

\subsubsection{How are the companies in terms of knowledge about the returns and their} causes?

One of the areas of work within RL is to reduce the returns through the analysis of their causes. Through the companies' presentations and visits we observed that the main causes of returns were associated with contractual agreements, excess of inventory at the bookstores, order mistakes and, end of promotional activities. Also, we could observe that there were different returns rates for different product categories (general editions, text books, etc). 
After exploring the main reasons, we conducted the exploratory survey (the questionnaire is in appendix I). Questions 1 and 2 from this questionnaire aimed to respond these questions: which are the main causes of returns and what is the returns rate in different product categories. Tables 5 and 6 summarize the results of this survey.

\begin{tabular}{|l|c|}
\hline Which are the main causes of returns? & Average \\
\hline A. Contractual agreements. & $42,6 \%$ \\
\hline B. Finalization of promotional activities. (including samples devolution & $20,2 \%$ \\
\hline C. Inventory excess (high amount of inventory in bookstore) & $22,0 \%$ \\
\hline D. Obsolete product (life cycle) & $7,0 \%$ \\
\hline $\begin{array}{l}\text { E. Inventory adjustments (seasonality effects: close of bookstores on } \\
\text { summer) }\end{array}$ & $6,2 \%$ \\
\hline F. Order mistakes & $1,6 \%$ \\
\hline G. Product damages & $0,4 \%$ \\
\hline
\end{tabular}

Table 5. Causes of returns (percentage are the average)

\begin{tabular}{|l|c|}
\hline What are your return percentages in: & Average \\
\hline A. General Editions & $25,7 \%$ \\
\hline B. Text books & $17,0 \%$ \\
\hline C. Samples & $0,3 \%$ \\
\hline D. Others & $0,3 \%$ \\
\hline
\end{tabular}

Table 6. Classification of products returned

In Table 5 we can observe that there are three causes that account for $84,8 \%$ of the returns. These causes are contractual agreements, inventory excess and finalization of promotional activities.

The impulse sale is very important in the book's market. Companies need to have high levels of inventory at the stores in order to promote sales. Editors establish some legal agreements with retailers in order to introduce as many books as retailers want. In these agreements editors accept to receive all the returned products. Retailers take advantage of these agreements and usually return the unsold products in order to adjust inventory.

The main causes of returns are associated with the commercial policy in the industry. On one hand retailers are not penalised by returns (because in most of 
the cases the cost of the returns is paid by the editor). And, on the other hand, editors follow a push strategy, pushing inventory to the stores. Editors have high stock levels due to the fact that the economic production batches are very big, and they prefer to have this stock at the stores than in their warehouses.

Table 6 shows an average return percentage of 25,7\% in general editions and a $17 \%$ in text books. Samples, which are those books sent to promote the sales (they cannot be sold) accounts for a 0,3\% of the returns and, magazines are not included in the table because none of the companies studied sell this kind of product.

\subsubsection{Which is the performance of the returns process?}

The second area of work within $\mathrm{RL}$ is the improvement of the RL process itself, in other words, to examine all the activities that have to be done in order to get the product back to the editorial company and look for any potential for improvement. To analyse this area of work, data was gathered from the companies' presentations, visits and the survey. We analysed the materials, information and monetary flows. From the companies' presentations and the discussions of the work group we detected the following main problems in the RL process:

Books are send in bad conditions, and therefore, they cannot be recovered and reused.

$>$ There is not information about retailers' and distributors' book sales. Therefore, it is not possible to estimate on time and accurately the success or failure of a book.

$>$ Returned books are not well specified. Clients do not send a detailed information about the books returned. This difficults the return process and leads also to disconformities between editors and clients in terms of the books returned.

In many cases, there is not a clear information about the causes of the returns. 
Some times, clients send the product back without an authorization and without informing the editor about it. This difficults the forecasting of personnel and resources to manage the returns.

As it can be appreciated, most of the problems pointed out are associated with the information flows: not information about sales, not information about books returned, not information about the causes of the returns and not communication of the return. Only one of the problems stated is related to the material flow: books returned in bad conditions.

Another aspect regarding the performance of the returns process has to do with the main causes of discussion between editors and clients regarding returns. Question 6 of the survey (see appendix I) helped us to identify the main causes of these discussions:

Return of damaged products (when damage is generated by the client).

Differences between the quantities informed by the client and the quantities received by the editor.

> Payment of transportation costs of the products returned.

> Return of products and placement of orders for the same books at the same time (some clients do this practice in order to have more lead time for the payment).

$>$ Lack of documentation and return excess (more than the authorized quantity).

The principal cause of discussion is the quality state of the products. There are only three companies that accept all the returned products. The extended policy is to accept only those products in which the client is not responsible for the damage.

Finally, other important issue to consider about the performance of the RL process is the cost of the returns. Questions 8, 9 and 10 from the questionnaire (see appendix I) helped us to analyse this aspect. Only seven of the eleven companies calculate the cost of a returned book (Companies 1,3,4,5,6,7 and 11) and they do it in different ways. Company 1 assign a percentage of the overhead costs to each book returned and considers also the direct labour, 
transportation and general expenditures. Companies 3 and 7 use Activity Based Costing to compute the cost of a book returned. They include the following activities in this calculation: transportation (delivery and recovery), optical reading, classification, relocation and, recovery process. Company 4 adds the annual reverse transportation cost, the personnel costs, the external manipulation cost and the overhead expenditures and then, divides the sum of all these costs by the number of books moved, assigning the same cost to a book returned than to a not-returned book. Finally, companies 6 and 11 did not provide the procedure they used to calculate the cost of the returned book.

Table 7 shows the distribution of costs, between the different activities in the returns process.

\begin{tabular}{|l|c|}
\hline What percentage of the return costs corresponds to: & \\
\hline A. Transportation costs & $16,5 \%$ \\
\hline B. Manipulation costs & $41,8 \%$ \\
\hline C. Storage costs & $1,8 \%$ \\
\hline D. Recovery process (when it is Outsourced) & $27,8 \%$ \\
\hline E. Depreciation and variable equipments and buildings costs & $6,3 \%$ \\
\hline F. Other Costs & $6,0 \%$ \\
\hline
\end{tabular}

Table 7. Distribution of costs in the Returns process

As it can be appreciated in table 7, most of the costs are due to the manipulation of the product. The recovery process cost corresponds to the recovery process when it is outsourced; therefore there is also manipulation costs within these costs. Transportation costs are also important, accounting for a $16,5 \%$ of the total cost. In general, we can say that the activities conducted to reduce the returns costs should be focused on these three items manipulation, recovery and transportation.

\subsubsection{Are companies creating value from the returns?}

Rogers et al. (1998) describe some general disposal activities for the returned products. We modified this list in order to adapt it to the editorial sector. These modifications were based on the information collected through the visits and companies' presentations. In the survey, companies were asked about the principal disposal activities they usually perform (see question 4 of the 
questionnaire). Table 8 shows the main disposal activities and the percentage of books that in average follow these disposal activities.

As we can observe, the products in the editorial sector have basically four types of disposal activities. Most of the products are recovered and returned to inventory, which means that editors probably can recover a high value from the returned products. However, returning products to inventory does not mean to recover the value, because the product must be sold again. If the recovered product is not sold, editors are losing value in the recovery process.

Another disposal activity is to destroy the products. This is mainly done to products that have been classified as "not recoverable". And finally, other disposal practices are: to sell the products through secondary markets or give them to charity. Given the fact that the highest value from the returned books is to recover them and send them back to inventory, other disposal activities, such as to give them to charity or to sell them through secondary markets, are basically "reserved" to obsolete or not recoverable products.

\begin{tabular}{|c|c|}
\hline \multicolumn{2}{|c|}{$\begin{array}{l}\text { ¿What is the percentage in which you perform each one of the } \\
\text { following practices with the returned products in your company? }\end{array}$} \\
\hline A. Product recovery and send back to inventory & $88,8 \%$ \\
\hline B. Destroy the product & $8,3 \%$ \\
\hline C. Give to charity & $1,5 \%$ \\
\hline D. Product recovery and sale to secondary markets & $1,3 \%$ \\
\hline E. Storage of the product (without recovery) & $0,0 \%$ \\
\hline F. Other activities & $0,0 \%$ \\
\hline
\end{tabular}

Table 8. Percentage of disposal activities in the sector.

\subsection{RQ3: How can the returns' management be improved?}

One of the main objectives of the work group was to find different possibilities of improvement in the returns management. In the following sections we describe the actions of improvement that can be undertaken in each one of the three areas of work: causes of returns, RL process improvement and value creation from returns.

\subsubsection{Can the returns be reduced?}


To reduce the returns we have to attack their causes. We discussed several alternatives to reduce the volume of returns through controlling the elements that generate them. The main cause of returns is the commercial policy of pushing the books to the stores because of the importance of the impulse sale. The editors participating in the work group recognised the problem but they concluded that they were not able to change this policy: To motivate their clients to buy their books it was very important to have the bookstores' stands plenty of books. However, the work group recognised that there was one possibility to reduce the returns: to have better forecasts. To improve forecasting these companies need appropriate software packages and real time information about sales. This latter aspect requires bookstores to share information about sales, and this means that editors and bookstores have to collaborate and change the actual type of relationship for one of a more partnership style.

\subsubsection{How can the RL process be improved?}

There is a large field of improvement in the operational process of the returns. Some of the ways in which they can work to improve the RL process are: to change some processes, to automate some of them, etc. However, the main area of improvement is in the management of information flows. As stated in section 5.2.2, there was not any sharing of information about sales and many of the stores were not informing about returns and neither about the causes of these returns. When asked about the most important information to collect, editors pointed out the following:

$>$ Inventory levels in the bookstores.

$>$ Sales forecasting.

Administrative information about the returns (i.e. number, quality, causes, etc)

Editors consider that the most useful information from the retailers is the point of sale information on real time because it can help them to evaluate if a book is successful or not at the beginning of the sales period. Editors also pointed out that information about returns (such as, number of books returned, causes of returns, quality state, etc) is relevant for the improvement of the RL process. We consider very important to remark that the relationship with suppliers and clients 
deserve all the editors' attention, given that most of the problems seem to arise from a bad coordination or understanding between the parties.

We asked editors if they should work with clients and distributors and which should be the priorities of their work. They pointed out as priorities of their joint work the following aspects:

$>$ Reduction of returns rate.

$>$ Improvement in the quality state of the products returned.

$>$ Improvement in the returns documentation (clients identification, returns description, etc).

$>$ Improvement in the transportation process.

$>$ Sharing of information in the returns process, (inform about the products that will be returned, make agreements about data exchange) .

> Standardization of process, with common procedures of returns for clients and suppliers.

$>$ Improvement in the planning process.

In order to improve the information flow and the quality of the returned products the work group defined common methods for the returns process. The group developed a document called "Best practices for books' returns" (see document in appendix II). This document was agreed by the editors participating in this study, the Spanish editors association, the bookstores' association of Madrid and the National Federation of books' distributors.

In order to improve the efficiency of the RL process the group is still working on the design of an optimal process of returns. Up to now two things are clear:

The optimum is to locate the refund before the recovery process of the product. In logistics terms, it is better to do the refund before the quality assessment process, but it implies that the commercial principle of receiving only good quality products (used by some editors) should be revoked.

> The optimum is to recover only those products that have a high probability of being sold again. Editors were spending a lot of money in recovering books which were not going to be sold. 
Regarding the efficiency of the RL process, the group also considered the possibility of creating a Return's Centre, but this solution was finally discarded because of some political and competitive reasons between the editors. However, given that this option has been very successful in some countries, like U.S.A and England ${ }^{3}$, there is still a possibility of retaking this issue in the future.

Finally, as stated in section 5.2.2 some companies were not calculating the cost of the returns and the ones calculating this cost were using different criteria. The work group decided that in order to improve the returns process it was very important to obtain good measures of the returns costs. Accordingly, we defined a method to calculate these costs. We used a spreadsheet to develop a tool to calculate the real costs of a returned product. Appendix VI shows the bases used to compute the cost. One interesting thing to remark from the cost calculation is that the transportation cost of a returned product is three times the transportation cost of a non-returned book. This is because the product goes and comes back to be sent again to another client. This is better explained with figure 3.

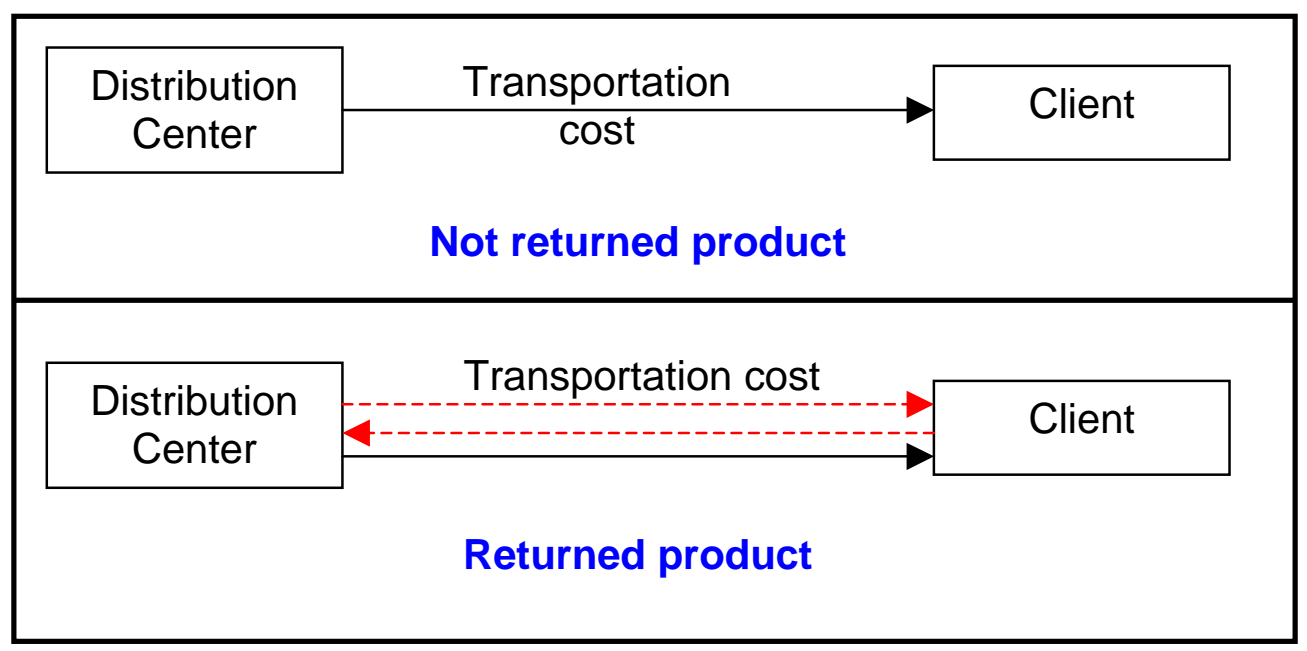

Figure 3.Transportation cost differences between a returned product and a product which is not returned.

Notice that returned products have been manufactured and distributed like a non-returned product, but in this case there is not money received for the client

\footnotetext{
${ }^{3}$ GENCO systems, is a company from USA that provides this service to companies in USA and England. During the development of this work, a meeting was maintained with Mr. John O' Hagan, Managing Director of GENCO in Europe. The financial statements of the company, show the success of this initiative in these countries. For additional information see www.genco.com.
} 
to compensate all the processes performed. In fact, returned products require additional processes: to take them back to the company, reprocess and reintroduce them into the inventory. Therefore the returned products are clearly more costly and less profitable than the non-returned ones.

\subsubsection{How to create more value added from the returns?}

Creating value from returns is not a priority in this sector. They obtain the highest value they can for most of their products, which is to recover and reintroduce them to the end-product inventory.

They can look for some alternatives for the residual part of the products, which are not reintroduced to the inventories (obsolete products, non-perfect quality products, etc.). However, given the low expected profit derived from these activities they are not a priority for them.

As it can be observed, in the editorial sector there is a field of improvement in each one of the three areas: Firstly, to reduce the number of returns, the work can be done basically in improving the forecasting and planning methods. The returns volume has to be incorporated in the planning tools to adapt them to the real situation. Secondly, in relation to the RL process improvement, it was concluded that the most important work should be done in the area of information management and costs calculations. And, finally, regarding the third area of work, create value from returns, it has to be stated that some field of improvement exists, but given the high volume of books that are finally reincorporated to the inventory, this area becomes less attractive than the others in terms of profitability.

The improvement of the $\mathrm{RL}$ processes related with the hypermarkets should have a high priority in the work. Analyse the return process in this case, given their volume in sales, and also working in reducing the high quantity of problems arising with them is something very important for the editorial companies.

\section{CONCLUSIONS AND FUTURE RESEARCH}

In this paper we explored the actual state of development of the editorial sector in Spain. As a result of the analysis, some projects were engaged by the 
authors and the principal companies in the books sectors. Up to now, have provided good results for the companies in terms of benchmarking and improvements in the returns process.

One of our objectives was to describe the state of art of the RL process in the Spanish book sector. This industry is characterized by a high return rate (nearly 1 of each two books sold is returned) and the high RL costs, the high unitary costs of processing the returned goods and the high return's volume of this sector leads to the high RL costs, being nearly two times the direct logistics costs. The main causes of returns are the contractual agreements, the finalization of promotional activities and the inventory excess, which together generate for the $84,8 \%$ of the returns. Other causes, in order of importance, are: obsolete products, inventory adjustments, order mistakes and product damage. This shows that most of the returns are because the contractual agreements and not by inefficiencies in the process. The general edition group has the highest returns rate $(25,7 \%)$, and has not seasonality. This complicates very much the RL process because increases the uncertainty about when, how and where the books will be returned.

Regarding the performance of the RL process, most of the problems are related with the sharing of information, in fact, retailers work independently from editors, without sharing sales and forecasting information. This leads to an increase in the inventory levels in the whole supply chain and, in some cases, stock outs, given the high uncertainty about the success or failure of a book.

In most of the cases $(88,8 \%)$, editors reincorporate the returned products into the inventory obtaining the highest value they can derive from the books returned. Other practices like destroy the products, give them to charity and sale in secondary markets are also performed for some companies but in a lower percentage.

We identified some potential for improvement, specially in two areas of work: To reduce the causes of returns and to improve the $R L$ process. To reduce the causes of the returns, it is very important to improve the forecasting and production planning techniques. Introducing the returned books as part of the planning process is a key aspect. In the second area, the most important work 
should be done in improving the information sharing between the supply chain members and in the standardisation of the RL process.

This study has some limitations, first of all some of the companies have not provided all the data requested. This was due to the internal policies of some of them. Another limitation is the reduced sample size. There are 2000 editors in Spain and we have only considered eleven companies. However, it must to be said that given the size of the companies in the study, we covered $50 \%$ of the sales of the editorial industry. The companies participating in the study were the most important ones in the Spanish editorial market.

But despite of these limitations we believe that this paper will be insightful for managers and researchers in the $\mathrm{RL}$ area. For managers, we provide some guidelines about how to perform a RL analysis identifying ways of improvement. This should lead to an increase of profitability in the whole business. In this way, managers can see RL as a profit potential area instead of a cost center. This process has been also a benchmarking opportunity for the companies participating in the study and can also be applied to other sectors and companies.

For researchers, the methodology used can also help those who want to develop sector analysis in the RL area. The work also provides some lines of further research: first, it is necessary to develop new models for forecasting and planning. In the editorial sector, models where the returns can be considered as part of the planning process should be object of further study. There is also a field of work in developing new cost accounting models based in Activity Based Costing to calculate the real cost of the returns. There is also a wide field of work in developing models that consider the effect of information sharing in planning the returns. And finally, there is also the possibility of investigating the possibility of creating a Central Return's Centre and its implications in terms of costs.

\section{BIBLIOGRAPHY}

- Barros, A.I. Dekker, R., Scholten, V., "A two-level network for recycling sand: A case study" 1998. European Journal of Operational Research 110, pp. 199-214 
- Dale S. Rogers, Ronald S. Tibben-Lembke. "Going Backwards: RL Practices and trends".1998, University of Nevada, Reno. Center of Logistics Management. RL Executive Council.

- Dowlatshahi, Shad. "Developing a theory of RL", Interfaces 30: 3 MayJune 2000 (pp 143-155)

- Fande, "VIII estudio de perfil del sector de la distribución de libros y publicaciones periódicas". 2003. Federación de Asociaciones Nacionales de Distribuidores de Ediciones. 128p.

- Fleischmann Moritz, Bloemhof-Ruwaard, Jacqueline M., Van der Laan, Erwin Van Nunen, Jo A.E.E. and Van Wassenhove, Luck N. "Quantitative models for RL: A review" (1997). European journal of Operational Research. pp 103, 1-17.

- Fraser Johnson, P. "Managing value in RL Systems", 1998. Logistics and Transports rev. Vol. 34, No. 3, pp. 217-227.

- Goodman, Ann . "Implementing Sustainability in Service Operations at Scandic Hotels", 2000. Interfaces, 30:3, pp.202-214.

- Kokkinaki, A.I., Dekker, R. Van Nunen, J., Pappis, C. "An exploratory study on Electronic commerce for RL",1999. Econometric Institute Report El 9950/A, Erasmus University of Rotterdam, The Netherlands.

- Krikke, Harold. "Recovery strategies and reverse logistic network design".1998. Thesis, University of Twente, Enschede, The Netherlands.

- Krikke, Harold., Van Harten, A., Schuur,P.C.. "Business case Roteb: recovery strategies for monitors".1999. Conputer \& industrial engineering 36, pp 739-757.

- Kroon and Vrijens, "Returnable containers: an example of RL", International Journal of Physical Distribution \& Logistics Management, Vol.25 No.2, 1995, pp 56-68.

- Lourenço R.,Helena and Soto, J.P. "Nuevas tendencias en Logística Inversa", 2003. Gestión de la cadena de suministro: Visión de futuro. Dossier especial. Centro Español de Logística.

- Malhotra, Naresh K., "Marketing Research, an applied orientation", 2004. International edition. Fourth edition. Prentice Hall, 713 p.

- Maslennikova, Irina and Foley, David. "Xerox's approach to sustainability". INTERFACES 30: 3 May-June 2000 (pp. 226-233)

- RLEC projects, "Apparel manufacturers survey", 1999. RL Executive Council. Chicago, IL. www.rlec.orgn

- RLEC projects, "Consumer electronics manufacturers survey", 1999. RL Executive Council. Chicago, IL www.rlec.org

- V.Daniel R. Guide, Jr., Vaidyanathan Jayaraman, Rajesh Srivastava, and W.C. Benton. "Supply-Chain Management for Recoverable Manufacturing Systems”, Interfaces 30: May - June 2000 (pp.125-142) 
- Voss, Chris; Tsikriktsis, Nikos and Frohlich ,Mark "Case Research in Operations Management". International Journal of Operations \& Production Management, Vol. 22 No. 2, 2002, pp. 195-219.

- White, J.A., "RL moves forward", 1994. Modern Materials Handling, Vol. 49, No. 1 (January) pp. 29.

- Yin, R.K. (1994). Case study research: Design and methods, Sage publications, USA. 


\section{APPENDIX I \\ RL SURVEY \\ EDITORIAL SECTOR}

In which percentage the following causes of return are present in your company?

$\%$
A. Contractual agreements.
B. Inventory excess (High amount of inventory in bookstore)
C. Inventory adjustments (Seasonality effects [Close of bookstores on summer])
D. Obsolete product (life cycle)
E. Finalization of Promotional activities. (including samples devolution)
F. Product damages
G. Order mistakes

Are there other important causes of returns? If yes, can you mention them? In which percentages?

What are the return rates of your company in each one of the following items?:
A. Text books
B.
General publications
C. Magazines
D.
Samples
E.
Others

What kind of useful information can be provided by your clients or distributors in order to improve the RL processes?

What is the percentage in which you perform each one of the following practices with the returned products?

$\%$
A. Recover the product and send back to inventory
B. Recover the product and sale to secondary markets
C. Give to charity
D. Storage of the product (without recovery)
E. Destroy the product
F. Other activities (Please describe) 
If you should work together with clients and distributors in $R L$, what do you believe are the priorities of your work?

What are the main causes of discussion with your clients in terms of return's management?

What kind of information do you think is useful to know in returns management?

Do you know what is the average cost of returning a book to your company?

Yes No

In case of yes, how do you calculate it? i.e. What are the elements included in this calculation?.

What percentage of the return costs corresponds to:
A. Transport
B. Labour
C. Storage
D. Manipulation
E. Equipments and buildings
F. Other costs 


\section{APPENDIX II \\ CONTENT OF THE DOCUMENT “BEST PRACTICES FOR BOOKS' \\ RETURN"4 \\ BEST PRACTICES FOR BOOKS' RETURN}

\section{INTRODUCTION}

The editorial sector, is highly affected by returns. This document is the result of a conjoint effort from the most representative editors in the Spanish books market. Our goal is to improve all the process regarding the returns activities.

Application of these principles and recommendations will help both editors and retailers. Editors, because it will facilitate the reception process and returns control, and retailers (bookstore owners) because they will benefit from a quicker refund of their money and a reduction of the discrepancies in the quantity and quality of the returned products.

These best practices are based on three critical processes: returns planning, technical conditions of returns and returns management. Some key elements are remarked for each one of them.

\section{Returns planning}

\section{COMUNICATION BETWEEN CLIENT AND SUPPLIER:}

Following bookstore requirements, it is recommendable to improve the quality and the fluency of the communication system between clients and suppliers, in order to obtain a better coordination in general and promotional activities.

\section{LOGISTIC CARD:}

For each client it will be created a logistic card (see Appendix IV) to write down the established agreements in terms of frequency and returns schedules.

\section{Technical conditions for returns}

\section{PRODUCT:}

Books must be returned in the same conditions in which they have been sent to the bookstores.

\section{PACKAGING:}

Product must be correctly packaged. Follow all the necessary steps to guarantee that the product wont be damaged during transportation. Take into account the following aspects:

- Adequate packaging dimensions.

\footnotetext{
${ }^{4}$ The appendix have only the contents of the document. The format in which it was published is different.
} 
- Package the books in horizontal position to avoid transportation damages.

- Use an external card to identify returns. Specify the number of packages and the sender.

- Please check if the box has been correctly closed.

- Complete with paper or other adequate material the spaces between books.

- All boxes should not have more than $15 \mathrm{kgs}$.

\section{RETURNS PROBLEMS:}

If there are bad quality products (if the editor is responsible for the damages), please write down it in the returns card. (see appendix III)

\section{Returns management}

\section{DELIVERY:}

The delivery of a new product, is not conditioned by the reception of the products that the client wants to return.

PRODUCT:

When a product is returned, please identify it by its bar code and the ISBN number. If the product does not have bar codes and neither ISBN, please identify it by the name of the product.

\section{RETURNS CARD:}

When returns cards are prepared, please verify that all necessary data are present. Keep a copy of the return card, and leave the original within the return box. To guarantee refunding, check that all information is right.

\section{RECEPTION CONFORMITY:}

If return is not accepted, it will be communicated to the client. 
APPENDIX III

Returns Card *

DATE

EDITOR'S NAME

\begin{tabular}{|c|c|}
\hline & CLIENT'S DATA \\
\hline CODE: & NAME: \\
\hline ADDRESS: & POSTAL CODE: \\
\hline CITY: & PHONE: \\
\hline
\end{tabular}

\begin{tabular}{|c|c|c|c|c|}
\hline \multicolumn{5}{|c|}{ RETURNED PRODUCT'S REGISTRY } \\
\hline No. & CODE & NAME & UNITS & OBSERVATIONS $^{(1)}$ \\
\hline 1 & & & & \\
\hline 2 & & & & \\
\hline 3 & & & & \\
\hline 4 & & & & \\
\hline 5 & & & & \\
\hline 6 & & & & \\
\hline 7 & & & & \\
\hline 8 & & & & \\
\hline 9 & & & & \\
\hline 10 & & & & \\
\hline 11 & & & & \\
\hline 12 & & & & \\
\hline 13 & & & & \\
\hline 14 & & & & \\
\hline
\end{tabular}

TOTAL PACKAGES:

Client's signature

(1) Quality state of returned product. (Ok - damaged)

* This is a sample of the data needed in the returns process. 


\begin{tabular}{|c|c|c|c|}
\hline \multicolumn{4}{|c|}{$\begin{array}{c}\text { APPENDIX IV } \\
\text { LOGISTIC'S CARD } \\
\text { COMPANY DATA }\end{array}$} \\
\hline \multirow[t]{2}{*}{ CLIENT } & \multicolumn{3}{|c|}{ EDITOR } \\
\hline & \multirow{5}{*}{$\begin{array}{l}\text { NAME: } \\
\text { Address: } \\
\text { Phone: } \\
\text { Fax: }\end{array}$} & & \\
\hline \multirow{4}{*}{$\begin{array}{l}\text { Address: } \\
\text { Phone: } \\
\text { Fax: } \\
\text { e-mail: }\end{array}$} & & & \\
\hline & & & \\
\hline & & & \\
\hline & & & \\
\hline & 'ISTICS & 'CENTERS & \\
\hline CLIENT & & & EDITOR \\
\hline Number: & & Number: & \\
\hline Delivery address: & & Delivery address: & \\
\hline Picking up address: & & Picking up address: & \\
\hline Contact person: & & Contact person: & \\
\hline Phone: & & Phone: & \\
\hline Fax: & & Fax: & \\
\hline
\end{tabular}

\section{RETURNS INFORMATION}

\section{OTHER INFORMATION}

\section{LOCAL HOLIDAYS:}

\section{VEHICLES RESTRICTIONS:}




\section{APPENDIX V \\ (ONLY FOR HYPERMARKETS)}

If it is necessary to use a price ticket, please use easy-removable and easycleaning materials.

Locate the price ticket in the back book cover. Do not write the price in the interior pages with pencil or any other mechanism.

Price ticket should be well located. i.e. without covering principal parts of the books (Title, bar code, logos, etc), since they are the identification elements of each book. 


\section{APPENDIX VI}

ITEMS INCLUDED IN THE CALCULATION OF THE COSTS FOR THE BOOKS RETURNED

Number of books sold

Number of returned books

$\%$ Books destroyed

$\%$ Books recovered

$\%$ Books in storage without recovery

Transportation costs:

- Total forward transportation costs

- Total costs of backward transportation

- Transportation costs between logistics centres because of returns

- - Income of pallets by returns

Reception of returned books

- Reception and initial preparation of returned products

- Optical reading and quality classification

o Personnel

o Maintenance and equipment depreciation

- Other additional classifications

o Personnel

o Maintenance and equipment depreciation

- Refund process and authorization

o Personnel

o Maintenance and equipment depreciation

Recovery, reintroduction to the inventory, elimination

- Books cleaning (Taking out the price tickets, etc)

o Personnel

o Equipment depreciation

o Other additional costs

- Reintroduction to the inventory

o Personnel

o Equipment depreciation

o Other additional costs

- Other Recovery costs

o Personnel

o Equipment depreciation

o Other additional costs

- - Income by elimination

Other costs

- Charge by overhead expenditures

- Administrative personnel salaries (\% of returns)

- Overhead expenditures (services)

- Other expenditures 
Returns area:

- Rent costs per warehouse/year

- Depreciation costs of warehouse/year

0 Buildings

o Equipments

o Shelves

o Others

- Maintenance costs per warehouse/year

o Personnel

o Equipments

o Others

- Warehouse space $\left(\mathrm{m}^{2}\right)$

- Returns area within warehouse $\left(\mathrm{m}^{2}\right)$ 